ISSN 1112-9867

\title{
STRENGTHENING THE MATERIAL-TECHNICAL BASE OF MODERN AGRARIAN FORMATIONS
}

\author{
A. A. Zamaidinov ${ }^{1}$, A. K. Subaeva ${ }^{2, *}$, T. N. Leonidovich ${ }^{3}$, N. M. Mingaliyevich ${ }^{4}$, V. T. \\ Vodyannikov $^{5}$ \\ ${ }^{1}$ The branch of Kazan (Volga region) Federal University in Chistopol, 422980, Chistopol, \\ Studencheskayastr, 15 \\ ${ }^{2}$ Federal State Budgetary Educational Institution of Higher Education, Ulyanovsk State \\ Agricultural Academy named after P.A. Stolypin, 432017, Ulyanovsk, bul'varNovyj Venec,1 \\ ${ }^{3}$ The Ministry of agriculture and food of the Republic of Tatarstan \\ ${ }^{4}$ The Ministry of agriculture and food of the Republic of Tatarstan \\ ${ }^{5}$ Russian state agrarian University-MTAA named after K. A. Timiryazev
}

Published online: 08 August 2017

\begin{abstract}
Technical and technological modernization of agriculture is an important direction of state support for agricultural production. At present, in agriculture there is a tendency of equipment obsolescence and break down. Partly, the deficit is compensated by means of acquisition of high-energy, high-performance equipment and the implementation of resource-saving technologies, the use of combined soil cultivating and sowing units. However, the equipment of agricultural producers remains at a level,which does not allow performing all technological operations in the normative agrotechnical terms, that leads to deficits and production losses. As a consequence, the role of state support in raising the level of agricultural machinery is becoming increasingly important [1]. The object of the study is the Volga Federal District (VFD). The study presents statistical data for 2000-2015. The analysis of the level of agricultural machinery in the regions of the Volga Federal District made it possible to divide all regions into three groups and to make recommendations for the development of technical
\end{abstract}

Author Correspondence, e-mail: subaeva.ak@mail.ru

doi: http://dx.doi.org/10.4314/jfas.v9i2s.79 
capacity. In this situation, the role of state support in raising the level of agricultural technology is becoming increasingly important.

Keywords: agricultural machinery, provision, load, technical availability, technical potential.

\section{INTRODUCTION}

Steady increase in agricultural production is connected, first of all, with the transformation and strengthening of the material and technical base. The means of production are one of the most important components of the resource potential, the material basis of agricultural production. Strengthening the material and technical basis of modern agrarian formations, proportional formation of its components, timely renewal and intensive reproduction are the main terms and conditions of effective production of agricultural products [2].

\section{METHODS}

The assessment of tractors availability showed, that in the dynamics of 2000-2015, the number of tractors per 1,000 hectares of arable land in the Russian Federation decreased 2.2 times, including 1.2 times for the past five years,amounted to 3.3 units. In the Volga Federal District, the supply of tractors in agriculture decreased from 6.9 to 3.0 units, or 2.3 times.

The highest rates of decline in the supply of tractors are observed in the Ulyanovsk Region (3.6 times), the Republic of Mari El (3.0 times), the Penza Region (2.9 times), the Republic of Bashkortostan (2.9 times), the Orenburg Region (by 2.8 times), the smallest decrease was in the Kirov region (by 28.1\%), the Republic of Tatarstan (by 33.3\%) and the Udmurt Republic (by $34.8 \%$ ).

Ranking of the Volga Federal Districts entities by the number of tractors per 1,000 hectares of arable land in 2015 made it possible to identify regions with a high level of provision (over 5.0 units), including the Kirov Region, the Udmurt Republic, the Republic of Tatarstan, the Perm Territory and the Chuvash Republic. Low level of supply with tractors (up to 3.0 units) is observed in Orenburg, Ulyanovsk, Penza and Saratov regions.

Availability of combine harvesters for 2000-2015 in the Volga Federal District and in the Russian Federation tends to decline. During the period under study, the number of combine harvesters per 1000 hectares of crops decreased 2.5 times. The highest rates of decline in the provision of combine harvesterswere defined in the Penza region (5 times), low rates were observed - in the Orenburg region (by 33.3\%).

Ranking of the VFD entities by the number of combine harvesters per 1000 hectares of cereal crops sowings, according to the data of 2015, showed that the low level of supply with the 
analyzed equipment is characteristic only for the Penza region, seven entities of the district had an average level, and six entities had high level.

A similar trend in the reduction of the level of provision with agricultural machinery was also revealed for other types of combines - potato harvesters and sugar beet combines. The availability of potato harvesters in the Russian Federation in 2000-2015 decreased 3.1 times, in the Volga Federal District - 2.2 times; the availability of sugar beet combines - respectively 5.3 and 7.5 times $[3,4]$.

For individual VFD entities, the annual rate of decline in the level of provision with agricultural machinery reaches $9 \%$ or more (Ulyanovsk, Saratov, Kirov regions, the Republic of Tatarstan).

Despite the considerable amount of new equipment, purchased over the last five years, that is due to the implementation of the subprogram "Technical and technological modernization, innovative development" of the State Program for Development of Agriculture and Regulation of Agricultural Commodity Markets for 2013-2020, the level of technical availability is reduced due to its intensive retirement.

\section{RESULTS}

There is a tendency of equipment obsolescence and break down, in agricultural sector. Partly, its deficit is compensated by means of acquisition of high-energy, high-performance equipment and the introduction of resource-saving technologies, using combined soil cultivating and sowing units [5]. However, the equipment of agricultural producers remains at a level, which does not allow performing all technological operations in the normative agrotechnical terms, and that leads to deficits and production losses. In this regard, as a measure of state support for the technical and technological modernization of agriculture, at the expense of federal budget, the subsidies were providedto producers of agricultural machinery, for reimbursement of expenses for the production of equipment, sold to agricultural producers at a discount, in the amount and according to the list, approved by a Decree of the Government of the Russian Federation from December 27, 2012 № 1432 "On approval of the rules for granting subsidies to agricultural technique producers. "

In 2015, the agreements on granting subsidies were concluded between the Ministry of Agriculture of the Russian Federation and 41 enterprises of agricultural machinery industry. The amount of paid subsidies amounted to 5194.9 million rubles. It was sold 6405 units of agricultural machinery, including 979 tractors, 2195 combine harvesters, 106 forage combine harvesters and 3125 units of other types of equipment. In the Volga Federal District the base 
quantity of agricultural machinery is supplied to the Republics of Bashkortostan and Tatarstan, Orenburg, Samara, and Saratov regions.

The park of machinery in agricultural organizationsis renovated for some types of equipment,but slowly. In 2015, the share of cars with a service life of more than ten years in Russia was $60.3 \%$ for tractors, $45.4 \%$ for combine harvesters. For forage combine harvesters, the share of machines with a service life of more than ten years was $42.9 \%$. However, there was no renovation of tractors and combine harvesters in the VFD.

Reduction of the vehicles and tractorspark led to an increase in the land load per item of agricultural machinery. In the dynamics of 2000-2015, the load per 1 tractor in Russia increased by a factor of 2.3 , including the increase by $24.3 \%$ in $2011-2015$. In the Volga Federal District, the load per 1 tractor increased by a factor of 2.3 , and by $24.6 \%$, respectively. The highest growth rates of land load were defined in the Ulyanovsk region (by a factor of 3.7). However, the highest load per 1 tractor was observed in the Orenburg region 666 hectares, in 2015. The lowest load per 1 tractor was defined in the Kirov region and in the Republic of Tatarstan - 146 and 167 hectares, respectively.

In 2000-2015, in the Russian Federation, the land load per 1 combine harvester has increased by a factor of 2.1, in the Volga Federal District - by a factor of 2.2, while over the past five years the growth rate of land load has slowed.

The lowest load per 1 combine harvester among the VFD entities was observed in the Kirov region and the Perm region - 296 and 307 hectares, respectively; the highest - in the Penza region - 726 hectares. The increase in land load was noted for other types of agricultural machinery.In Russia the load per 1 potato harvester increased by a factor of 3, per 1 beet root combine - by a factor of

6.4; in the Volga Federal District the load per 1 potato harvester increased by a factor of 2.1, per 1 beet root combine - by a factor of 6.6.

Universal indicator, characterizing the provision of production with technical resources is energy supply, which reflects the aggregate of all the powerful technical resources of the enterprise(tractors, combines, other self-propelled machinery, power plants, milking machines, etc.) $[6,7]$.

In the dynamics of 2000-2015, the level of energy supply of agriculture in the Russian Federation has decreased from 329 to $197 \mathrm{hp}$. or 1.67 times. In the VFD regions, the average rate of decline of this indicator was 4.0\% annually. The Republic of Mari El and Chuvashia, the Kirov and Nizhny Novgorod regions are characterized by the greatest provision of energy supply, the least - the Orenburg, Saratov and Ulyanovsk regions. At the same time, the 
Ulyanovsk region has the highest rate of decline in energy supply - annually by $6.8 \%$. The analysis of the technical potential of agricultural development has made it possible to divide the regions of the Volga Federal District into three groups.

\section{DISCUSSION}

In this situation, the role of state support in raising the level of agricultural technology is becoming increasingly important. However, it should be noted, that state support is provided to agricultural producers of agricultural machinery and equipment without taking into account the confirmation of its effectiveness, which makes the process of re-equipment more risky and costly $[8,9]$.

In accordance with the Federal Law "On the Development of Agriculture", the Ministry of Agriculture of Russia was entrusted with the authority to organize work, aimed at determining the functional characteristics and effectiveness of agricultural machinery and equipment, the results of which would be taken into account when providing government support $[10,11]$. The order of the organization of these works and the criteria for determining the functional characteristics and efficiency of agricultural machinery and equipment, the list of activities for which state support is provided, taking into account the results of these works, are established by the Government of the Russian Federation.

\section{SUMMARY}

The Ministry of Agriculture of the Russian Federation has developed a mechanism for determining the functional characteristic, which assumes the use, as information, contained in the technical and operational documentation of the manufacturer and the test results of equipment and installations, federal state budgetary institutions - machine stations in soil and climatic zones of use.

\section{CONCLUSIONS}

This mechanism will allow to provide state support for efficient agricultural machines, which meet the established functional characteristics.

\section{ACKNOWLEDGEMENTS}

The work is performed according to the Russian Government Program of Competitive Growth of Kazan Federal University. 


\section{BIBLIOGRAPHY}

[1] State Program for Development of Agriculture and Regulation of Agricultural Commodity Markets for 2013-2020 [Electronic resource] Access mode: http://www.mcx.ru/docuirients/

[2] Strategy for the development of agricultural machinery manufacturing in Russia until 2020 [Electronic resource]. Access mode: http://www.rosagromash.ru/attachments/ Development $\% 20$ Strategy.doc (Access date: 16.10.2012).

[3] Statistical book of the Russian Academy of Agricultural Sciences (Department of Economics and Land Relations of the Russian Academy of Agricultural Sciences) M.: Russian Academy of Agricultural Sciences. - 2012. P.32.

[4] Statistical Yearbook. The Republic of Tatarstan. - 2014: Coll./ Territorial body of the Federal State Statistics Service of the Republic of Tatarstan. Kazan: Tatarstanstat, 2014. 521 p.

[5] Polukhin, A.A. Features of the use of technical potential of Russian agriculture at the regional level / A.A. Polukhin // Education, Science and Production. - 2013. - No. 2 (3). - Pp. $16-21$.

[6] Vodyannikov, V.T., Sereda, N.A. Reproduction of the technical potential of agriculture in the conditions of innovative development: monograph / V.T. Vodyannikov, N.A. Sereda. Karavaevo: Kostroma State Agricultural Academy, 2014. - 228 p.

[7] Vodyannikov, V.T., Rubtsov, P.A.The analysis of technical provision of agricultural organizations in the Republic of Mordovia / V.T. Vodyannikov, P.A. Rubtsov. // Bulletin of the Federal State Educational Institution of Higher Professional Education "Moscow State Agroengineering University named after V.P. Goryachkin. " - 2013. - №3. - Pp. 79-82.

[8] Van Duijn J.J. Fluctuations in innovations over time. - Futures, 1981. Vol.13, - № 4. Pp. 264-273.

[9] Europe 2020. A strategy for smart, sustainable and inclusive growth. - European Commission, 2002, COM(2010) 2020 final.

[10] Subaeva A.K., Zamaidinov A.A. Classification of agroindustrial complex technical provision effectiveness indexes/ A.K. Subaeva, A.A. Zamaidinov A.A. // JOURNAL OF economics and Economic education research 2016; 4(17): 8-14,issn: 1533-3590.

[11] Subaeva A.K., Zamaidinov A.A. Methods of agricultural machinery market regulation / A.K. Subaeva, A.A. Zamaidinov A.A. // International Business Management 2015; 9(7): 1780-1784. ISSN: 1993-5250. 


\section{How to cite this article:}

Zamaidinov A A, Subaeva A K, Leonidovich T N, Mingaliyevich N M, Vodyannikov V T. Strengthening the material-technical base of modern agrarian formations. J. Fundam. Appl. Sci., 2017, 9(2S), 1052-1058. 